\title{
MULTICRITERIAL ANALYSIS OF THE CHOICE OF WASTE UTILIZATION TECHNOLOGY USING PAIR COMPARISONS
}

\section{T. Hrebeniuk, N. Remez, V. Prokopenko, V. Bronytskyi}

National Technical University of Ukraine "Igor Sikorsky Kyiv Polytechnic Institute" vul. Borshchahivska, 115, Kyiv, 03056. Ukraine, E-mail: t.hrebeniuk07@ gmail.com

There are two broad types of landfill strategies. Traditional landfills, which are uncontrolled, allow the release of pollutants into the soil without restrictions. This method is not considered suitable for operation due to the serious risk that groundwater leaching and potential landfill gas accumulation may be caused. Therefore, modern landfills should be controlled and operated on a 'maintenance' basis, which avoids environmental pollution. Domestic landfills are major sources of air pollution from greenhouse gas emissions. Important issues of domestic landfills, which are sources of air pollution due to greenhouse gas emissions, are analyzed. The gas released in landfills can contain various components that are known to cause 'greenhouse effects'. Emissions from landfills of gas and wastewater can occur for decades and hundreds of years. Methods of solid waste disposal are considered (MSW). Solutions for solid waste management must be financially sustainable, technically feasible, socially, legally acceptable and environmentally friendly. In the course of this work, comparisons of existing methods of heat treatment of waste were made. When comparing the main technologies of solid waste disposal, the following questions are usually asked: which of them is more important or more significant; which is more likely; which has a greater advantage, etc. Starting with the assessment of the feasibility of implementing a specific waste management technology, two tasks are solved: to select waste treatment technologies and to develop a system of criteria according to which the analysis will be conducted. Several types of equipment are used for waste incineration: incineration in rotary kilns, heat treatment using pyrolysis, fluidized bed incineration, incineration on mechanical grate, and incineration in metallurgical or cement kilns. According to the results of the study, the effectiveness of five alternative methods of waste treatment was evaluated on the basis of 8 criteria with using the method of hierarchical analysis. The technology for waste disposal was substantiated by incineration in drum / rotary kilns. According to the vector of global priorities, the value of this technology is almost twice the value of the next 'optimal' technology.

Key words: landfills, pollution, technologies of utilization, waste, heat treatment, analysis of comparisons.

\section{БАГАТОКРИТЕРІАЛЬНИЙ АНАЛІЗ ВИБОРУ ТЕХНОЛОГІЇ УТИЛІЗАЦІЇ ВІДХОДІВ З ВИКОРИСТАННЯМ ПАРНИХ ПОРІВНЯНЬ}

\section{Т. В. Гребенюк, Н. С. Ремез, В. В. Прокопенко, В. О. Броницький}

Національний технічний університет України «Київський політехнічний інститут імені Ігоря Сікорського» вул. Борщагівська, 115, м. Київ, 03056, Україна. E-mail: t.hrebeniuk07@ gmail.com

Існує два широкі типи стратегій звалищ. Традиційні звалища, які є неконтрольованими, дозволяють викид забруднюючих речовин у грунт без обмежень. Цей метод не вважається придатним для експлуатації через серйозний ризик, що може спричинити вимивання підземних вод та потенційне скупчення газу на звалищі. Тому сучасні сміттєзвалища слід контролювати та експлуатувати на основі «технічного обслуговування», що дозволяє уникнути забруднення навколишнього середовища. Внутрішні звалища є основними джерелами забруднення атмосферного повітря викидами парникових газів. Проаналізовано важливі питання побутових сміттєзвалищ, які є джерелами забруднення атмосферного повітря, грунтів та підземних вод. Газ, що виділяється на звалищах, може містити різні компоненти, які, як відомо, викликають «парникові ефекти». Викиди із звалищ газу та стічних вод можуть відбуватися протягом десятиліть і сотень років. Розглянуто методи утилізації твердих побутових відходів. Рішення щодо поводження з твердими побутовими відходами мають бути фінансово стійкими, технічно здійсненними, соціально, юридично прийнятними та екологічно чистими. В ході даної роботи було проведено порівняння існуючих методів термічної обробки відходів. При порівнянні основних технологій захоронення твердих побутових відходів, як правило, задаються такі питання: яка 3 них є більш важливою або більш значущою; що є більш вірогідним; що має більшу перевагу і т. д. Починаючи з оцінки доцільності впровадження конкретної технології поводження з відходами, вирішуються дві задачі: вибрати технології поводження з відходами та розробити систему критеріїв, відповідно до яких буде проводитися аналіз. Для спалювання відходів використовується декілька типів обладнання: спалювання в обертових печах, термічна обробка 3 використанням піролізу, спалювання в киплячому шарі, спалення на механічній решітці, спалювання в металургійних або цементних печах. За результатами дослідження оцінювали ефективність п'яти альтернативних методів поводження з відходами на основі 8 критеріїв, використовуючи метод ієрархічного аналізу. Обгрунтована технологія утилізації відходів шляхом спалювання в барабанних / ротаційних печах. Відповідно до вектора глобальних пріоритетів, цінність цієї технології майже вдвічі перевищує вартість наступної «оптимальної» технології.

Ключові слова: сміттєзвалища, забруднення, технології утилізація, відходи, термічна обробка, аналіз порівнянь.

PROBLEM STATEMENT. The design and operation of municipal solid waste (MSW) sites or landfills may affect the time period during which significant nat- ural changes occur, with negative environmental consequences. Two broad types of landfill strategies can be distinguished. Traditional landfills, which are uncontrol- 
lable, allow the release of pollutants into the soil without restrictions. This waste collection method is not considered appropriate for operation due to the serious risk that groundwater disposal and potential landfill gas accumulation may entail. Therefore, modern landfills should be controlled and operated according to the principle of 'content', which avoids environmental pollution.

Domestic landfills are significant sources of air pollution from greenhouse gas emissions. These components are two main carbon compounds: methane $\left(\mathrm{CH}_{4}\right)$ and carbon dioxide $\left(\mathrm{CO}_{2}\right)$ [1-2].

It is believed that the maximum level of landfill gas production will be reached in months-years after the closure of the landfill and after that will exponentially decrease, reaching insignificant volumes in about 25-30 years [3].

The amount of precipitation generated depends mainly on the amount of precipitation in the region and the type of landfill cover, which affects both the amount of moisture penetrating the landfill and the initial humidity of the waste. According to [4], the infiltration level should be estimated for each landfill where more accurate information is required, as opposed to using average or regional averages due to the large difference between sites. For example, at the stage of operation of the landfill, from 20 to $70 \%$ of precipitation penetrates into the landfill.

Typical materials from the landfill entering the soil and water are shown in Table 1 [5].

Table 1-Type emissions from landfill to soil and water

\begin{tabular}{|l|c|}
\hline \multicolumn{1}{|c|}{ Component } & Example \\
\hline Main ions & $\mathrm{Ca}, \mathrm{K}, \mathrm{Na}, \mathrm{NH} 4, \mathrm{CO}_{3}, \mathrm{SO}_{4}, \mathrm{Cl}$ \\
\hline Heavy metals & $\mathrm{As}, \mathrm{Cd}, \mathrm{Cr}, \mathrm{Pb}, \mathrm{Hg}, \mathrm{Cu}, \mathrm{Ni}$ \\
\hline Organic compounds & $\begin{array}{c}\text { Chlorinated organic, phenol, } \\
\text { benzene, specific pesticides }\end{array}$ \\
\hline Other & Microbiological components \\
\hline
\end{tabular}

Solid waste management is an acute and pervasive problem in both urban and rural areas in many developed and developing countries. The collection and disposal of solid domestic waste is one of the main problems of the urban environment in most countries of the world today. MSW management decisions should be financially sustainable, technically implemented, socially, legally acceptable and environmentally sound. Solid waste management is the biggest challenge for the authorities of both small and large cities.

Recycling is considered incineration and coincineration with a high level of energy recovery; conversion of wastes into materials used as solid, liquid or gaseous fuel.

In turn, it is energy utilization that is divided into three main types:

1. Collection of biogas at landfills and landfills with subsequent production of electrical and/or thermal energy;

2. Mechanical and biological treatment of MSW with possible production of biogas and/or solid fuel with MSW with subsequent use in cement plants or in specialized CHP/boiler houses;
3. Thermal treatment/processing of mixed (residues after sorting) MSW followed by power and/or heat generation

Thermal treatment of MSW is the most effective method of waste reduction and disposal. The following types of heat waste disposal are possible [6]:

1) production of heat and electricity from $\mathrm{RDF}(\mathrm{Re}-$ fuse Derived Fuel)/SRF (Solid Recovered Fuel) obtained after mechanical and biological treatment;

2) classic incinerator - incineration of a mixed MSW stream after extraction of valuable raw materials;

3) experimental technologies: gasification, pyrolysis.

MATERIAL AND RESULTS. Incineration is now becoming increasingly common and is seen in developed countries as the main method for recycling waste that cannot be recycled on technical or economic grounds.

Based on studies [7-9], the main generally accepted requirements for the combustion process are formulated, the implementation of which will ensure the prevention of the formation of dioxins in waste gases:

- high temperatures $\left(1250^{\circ} \mathrm{C}\right.$ or more);

- availability of an oxide-reducing medium;

- the residence time of flue gases in the high temperature zone sufficient to decompose dioxins;

- cooling flue gases as quickly as possible to prevent the formation of secondary dioxins;

- multi-stage system for cleaning flue gases from harmful components;

- high level of automation of thermal waste disposal process.

The combined fulfillment of all these conditions leads to the complete and irreversible destruction of dioxins and the purification of flue gases to a level safe for the environment and human health.

In the course of this work, comparisons were made between the existing methods of thermal treatment of waste: a movable grid with air cooling, with liquid cooling, a static grid with an ash/waste transportation mechanism, a rotary furnace, a boiling layer, a boiling layer rotating, circulating, and gasification - fixed layer, entrained flow, liquid layer, pyrolysis - short drum, middle drum Comparison was carried out according to:

- main characteristics of wastes that can be disposed of;

- capacity per line;

- advantages;

- disadvantages;

- ash quality;

- flue gas volume;

- installation cost information.

According to the results of the study, the effectiveness of five alternative waste treatment methods was assessed on the basis of 8 criteria. The steps for applying the hierarchical analysis method were as follows. There is pairwise comparison of the validity criteria on a nine-point scale with the addition of data to the corresponding matrix of size (nxn). The element of the matrix a $(i, j)$ is the intensity of development of the element of the hierarchy and relative to the element of the hierarchy $\mathrm{j}$, which is estimated on an intensity scale from 1 to $9[10]$, where the estimates have the values given in Table 2 . 
When comparing the main technologies for recycling MSW, the following questions are usually asked: which of them is more important or more significant; which is more likely; which has a greater advantage, etc.

The result is a matrix of paired comparisons of order A. In the process of filling the matrix, if element $i$ is more important than element $j$, the cell $(i, j)$ corresponding to row $i$ and column $j$ is filled with an integer, and if element $\mathrm{j}$ is more important than element and, then cell $(i, j)$ is filled with a full number.

Table 2 - Intensity assignment

\begin{tabular}{|c|c|}
\hline $\begin{array}{c}\text { Relative } \\
\text { importance } \\
\text { intensity }\end{array}$ & Definition \\
\hline 0 & variants cannot be compared \\
\hline 1 & equal importance \\
\hline 3 & $\begin{array}{c}\text { moderate advantage of one over } \\
\text { the other }\end{array}$ \\
\hline 5 & significant or strong advantage \\
\hline 7 & significant advantage \\
\hline 9 & very big advantage \\
\hline $2,4,6,8$ & $\begin{array}{c}\text { intermediate decisions between } \\
\text { two adjacent judgments }\end{array}$ \\
\hline
\end{tabular}

To calculate eigenvectors according to this method, you need to multiply the elements in each row and take the root of the nth degree, where $n$ is the number of elements. The result of the column of numbers was normalized by dividing each number by the sum of all numbers. Another way is to normalize the elements of each column of the matrix and then average each row. Ranking of elements that are analyzed using a pairwise comparison matrix is based on calculations of the main eigenvector of this matrix. The main eigenvector is determined by the equation $[11,12] \mathrm{OV}=\lambda_{\max } \mathrm{W}$, where $\lambda_{\max }$ is the maximum eigenvalue of matrix $\mathrm{A}$.

The consistency index (designation ' $\mathrm{CI}$ ') in each matrix and for the entire hierarchy can be calculated as follows: First, each judgment column is added, then the sum of the first column is increased by the value of the first component of the normalized priority vector, the sum of the second column is increased by the second component, etc. The resulting numbers are then compiled together. We can get a value called $\lambda_{\max }$. For the consistency index, we have $\left.C I=\lambda_{\max }-n\right) /(n-1)$, where $n$ is the number of elements to compare. For a wraparound matrix is always symmetric.

The general conditions for all technologies are as follows: minimum combustion temperature $850{ }^{\circ} \mathrm{C}$; Minimum residence time of exhaust gases is two seconds after the last combustion air supply; optimal oxygen content (less than 6\%); The carbon monoxide content of exhaust gases is a key indicator of combustion quality; flue gases are treated with multistage cleaning system.

Starting from the assessment of the feasibility in implementing a specific waste management technology, two tasks are solved:

1. Select waste treatment technologies.

2. Develop a system of criteria for analysis.
For waste incineration, several types of equipment are used: incineration in rotary furnaces $-S_{1}$, thermal treatment using pyrolysis $-S_{2}$, incineration in a boiling bed $-S_{3}$, incineration on mechanical grates $-S_{4}$, incineration on metallurgical or cement furnaces $-\mathrm{S}_{5}$. Options for multi-criteria analysis:

$$
S=\left\{S_{1}, S_{2}, S_{2,}, S_{4}, S_{5^{x}}\right\}
$$

Criteria by which options were assessed:

$\mathrm{C}_{1}$ - lowest level of negative impact on the environment;

$\mathrm{C}_{2}$ - independence of combustion efficiency from pre-treatment or sorting of garbage (necessity of grinding and improvement of homogeneity);

$\mathrm{C}_{3}$ - the ability to generate heat and electricity for various use systems;

$\mathrm{C}_{4}$ - complexity of equipment (easy maintenance, reliable operation);

$\mathrm{C}_{5}$ - amount of generated wastes, volume of flue gases (solid waste incineration; degree of concentration);

$\mathrm{C}_{6}$ - equipment installation area;

$\mathrm{C}_{7}$ - equipment cost;

$\mathrm{C}_{8}$ - public recognition (public opinion).

Thus, we have many criteria by which technology options were evaluated:

$$
C=\left\{C_{1}, C_{2}, C_{9}, C_{4}, C_{5}, C_{6,}, C_{7}, C_{8}\right\} .
$$

Options for heat treatment of waste:

- Combustion in drum (rotary) furnaces $\left(S_{1}\right)$;

- Thermal treatment using pyrolysis (gasification) $\left(\mathrm{S}_{2}\right)$

- Fluidized bed combustion $\left(\mathrm{S}_{3}\right)$;

- Burning on mechanical grates $\left(\mathrm{S}_{4}\right)$;

- Incineration in metallurgical or cement furnaces $\left(\mathrm{S}_{5}\right)$.

Criteria for variants of heat treatment technologies with the specified characteristics [13-17]:

1. Lowest level of negative environmental impact $\left(\mathrm{C}_{1}\right)$ :

- Slow rotation of the drum gives a processing time of 30 to 90 minutes. Temperatures between 850 and $1000{ }^{\circ} \mathrm{C}$ are sufficient to eliminate hazardous wastes that do not contain chlorine. For the destruction of chlorine-containing waste, a temperature of 1100 to $1200-\mathrm{C}$ is required $\left(\mathrm{S}_{1}\right)$;

- $\quad$ Flue gases generated in pyrolysis plants contain less dust than in conventional combustion plants, but more auxiliary fuel is consumed here and therefore the volumes of source gases are large $\left(\mathrm{S}_{2}\right)$;

- Particles can slip and remain in the bed longer than the average residence time. It is possible to reduce SO2 emissions by limestone and provide a relatively low NOX due to low combustion temperature $\left(S_{3}\right)$;

- Incineration of medical waste is possible. If contaminated waste is incinerated in these ovens, it must be previously disinfected and sterilized or placed in stoves in specially self-loading containers $\left(\mathrm{S}_{4}\right)$;

- At $1700{ }^{\circ} \mathrm{C}$, the content of harmful substances can be minimized, but polycyclic aromatic hydrocarbons can be formed at the outlet of the plant $\left(\mathrm{S}_{5}\right)$; 
2. Independence of combustion efficiency from pre-treatment or waste sorting (need for grinding and homogeneity) $\left(\mathrm{C}_{2}\right)$ :

- Requirements for composition and properties of raw materials are less stringent than in any other combustion method. The technology is complex in the field of processing large-sized wastes with variable composition; waste with high ash and humidity can be burned. Good heat exchange conditions are created from the heated gases to the treated material. Actually, all waste, regardless of type and composition, can be disposed of $\left(\mathrm{S}_{1}\right)$;

- Inefficient in handling heterogeneous wastes, such as MSW, requiring high pre-sorting costs $\left(\mathrm{S}_{2}\right)$;

- MSW with low ash melting points cannot be burned. Heavy physical impurities (metal particles in waste) can enter the air separation plate, interfere with fluidization and are difficult to remove from the furnace. There are restrictions on the distribution of shares by size and calorific value of $\mathrm{MSW}\left(\mathrm{S}_{3}\right)$;

- The presence of metal particles in waste at high temperatures complicates the operation of grids and requires additional purification $\left(\mathrm{S}_{4}\right)$;

- Requirements for composition and properties of raw materials are less stringent than for many other combustion methods. However, when toxic components enter the waste, toxic gases can enter the atmosphere $\left(\mathrm{S}_{5}\right)$;

3. Ability to generate heat and electricity for different use systems $\left(\mathrm{C}_{3}\right)$ :

- Provides a significant amount of energy in the form of steam and/or electricity that is cleaner than energy from oil, coal or natural gas $\left(\mathrm{S}_{1}\right)$;

- Low energy efficiency compared to conventional combustion. Due to the high level of combustibles in the solids during pyrolysis, the fuel consumption is about 1.6 times lower than in the case of conventional combustion $\left(\mathrm{S}_{2}\right)$;

- Consumption of significant amount of energy resources by the plant itself $\left(\mathrm{S}_{3}\right)$;

- Relatively large heat losses with mechanical (7-14\%) and chemical (up to 2-5\%) underperformance $\left(\mathrm{S}_{4}\right)$;

- It is not possible to obtain heat and electricity (the main production units are usually not equipped with heat recovery systems, except for heat for technological purposes) $\left(\mathrm{S}_{5}\right)$;

4. Complexity of equipment (easy maintenance, reliable operation) $\left(\mathrm{C}_{4}\right)$ :

- Characterized by mechanical reliability. However, the use of expensive thermo and chemically stable linings in drum furnaces results in increased unit and maintenance costs $\left(\mathrm{S}_{1}\right)$;

- High requirements for process control system to avoid emergency situations $\left(\mathrm{S}_{2}\right)$;

- Relatively complex equipment providing a mode of pseudo-reflection of the material to be treated $\left(\mathrm{S}_{3}\right)$;

- Possibility to use finished existing equipment, presence of rotating elements in high temperature zone $\left(\mathrm{S}_{4}\right)$
- $\quad$ Possibility to use the existing furnaces in production. However, the main production furnaces are quite complex devices $\left(\mathrm{S}_{5}\right)$;

5. Amount of waste generated, flue gas volume (solid waste incineration; degree of concentration) $\left(\mathrm{C}_{5}\right)$ :

- Good completeness of MSW burnout. The amount of ash residue is $5-10 \%$ of the initial waste volume, low dust content in gases. Complete combustion of the organic component and frying of slag, which is only possible in the drum oven $\left(\mathrm{S}_{1}\right)$;

- Satisfactory completeness of MSW burnout. Heavy metals do not melt, but exit with slag $\left(\mathrm{S}_{2}\right)$;

- Satisfactory completeness of MSW burnout. However, there is a possibility of solid bonding and sticking $\left(\mathrm{S}_{3}\right)$;

- Good completeness of MSW burnout. Window, formation of toxic slag, slipping of small parts in chassis space is possible $\left(\mathrm{S}_{4}\right)$;

- Good completeness of MSW burnout. The residues are part of the product (cement) or can be used as flux (in metallurgy) $\left(\mathrm{S}_{5}\right)$;

6. Equipment installation area $\left(\mathrm{C}_{6}\right)$ :

- Small space required for the organization of production $\left(\mathrm{S}_{1}\right)$;

- $\quad$ Relatively small area required for the organization of production $\left(\mathrm{S}_{2}\right)$;

- $\quad$ Large area required for organization of production $\left(\mathrm{S}_{3}\right)$;

- Large area required for organization of production $\left(\mathrm{S}_{4}\right)$;

- Small space required for the organization of production. The main production (metallurgical or cement) is not compact, but the additional space for organizing the combustion of TBT is small) $\left(\mathrm{S}_{5}\right)$;

7. Equipment cost $\left(\mathrm{C}_{7}\right)$ :

- Small initial investments; Cost-to-capacity dependence $\left(\mathrm{S}_{1}\right)$

- Moderate initial investment but need qualified personnel $\left(\mathrm{S}_{2}\right)$;

- Moderate initial investments, but qualified personnel are needed $\left(\mathrm{S}_{3}\right)$;

- Moderate initial investment, need to repair equipment after incineration of unsorted $\mathrm{MSW}\left(\mathrm{S}_{4}\right)$;

- Small initial investments; Cost dependence on capacity. Economic advantages at low processing costs due to the use of existing equipment $\left(\mathrm{S}_{5}\right)$;

8. Public recognition (public opinion) $\left(\mathrm{C}_{1}\right)$ :

- Neutral ratio $(\mathrm{S} 1)$;

- Neutral attitude. There are negative examples of an ECU for the treatment of automobile tires with insufficient and uncontrolled cleaning $\left(\mathrm{S}_{2}\right)$;

- $\quad$ Neutral ratio $\left(S_{3}\right)$;

- Moderately neutral attitude. The technology is understandable to the public, since it is similar to the technology of burning solid fuels in boiler furnaces and heating furnaces in private houses $\left(\mathrm{S}_{4}\right)$;

- Neutral attitude. Combustion of MSW in metallurgical or cement furnaces can be negatively perceived by personnel working in the existing metallurgical cement production $\left(\mathrm{S}_{5}\right)$. 
According to [18], calculation was made according to 8 criteria of 5 variants of the technology of thermal treatment of waste. The highest value of the global priority determines the best case according to the multicriterion evaluation method.

An example of calculation for the first criterion is given - the lowest level of negative impact on the environment.

1. Filling in the matrix of paired comparisons.

$$
\begin{aligned}
A C 1 & =\left(\begin{array}{ccccc}
1 & A C 1_{01} & A C 1_{02} & A C 1_{03} & A C 1_{04} \\
A C 1_{10} & 1 & A C 1_{12} & A C 1_{13} & A C 1_{14} \\
A C 1_{20} & A C 1_{21} & 1 & A C 1_{23} & A C 1_{24} \\
A C 1_{30} & A C 1_{31} & A C 1_{32} & 1 & A C 1_{34} \\
A C 1_{40} & A C 1_{41} & A C 1_{42} & A C 1_{43} & 1
\end{array}\right) \text { (3) } \\
A C 1 & =\left(\begin{array}{ccccc}
1 & 4 & 3 & 5 & 6 \\
0,25 & 1 & 0,5 & 3 & 2 \\
0,333 & 2 & 1 & 1 & 1 \\
0,2 & 0,333 & 1 & 1 & 1 \\
0,167 & 0,5 & 1 & 1 & 1
\end{array}\right)
\end{aligned}
$$

2. Define the geometric mean for each row in the matrix.

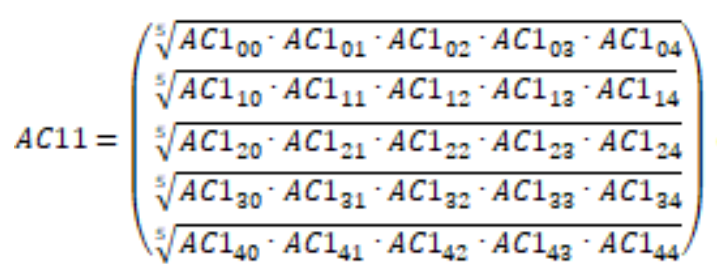$$
A C 11=\left(\begin{array}{l}
3,245 \\
0,944 \\
0,922 \\
0,582 \\
0,608
\end{array}\right)
$$

3. Finding Sum of Average Elements:

$$
\sum A C 11=6,302 \text {. }
$$

4. Define Local Priority Vector.

$$
A C 111=\left(\begin{array}{c}
\frac{A C 1_{0}}{\sum A C 11} \\
\frac{A C 1_{1}}{\sum A C 11} \\
\frac{A C 1_{2}}{\sum A C 11} \\
\frac{A C 1_{3}}{\sum A C 11} \\
\frac{A C 1_{4}}{\sum A C 11}
\end{array}\right)
$$

5. Find the sum of the elements of the corresponding columns in the matrix.

$$
\begin{aligned}
& \sum A C 1^{(0)}=1,95^{;} \\
& \sum A C 1^{(1)}=7,833_{;} \\
& \sum A C 1^{(2)}=6,5 ; \\
& \sum A C 1^{(3)}=11_{;} \\
& \sum A C 1^{(4)}=11
\end{aligned}
$$

6. Determination of design value $\lambda_{\max }$.

$$
\begin{gathered}
\lambda_{1}=\sum A C 1^{(0)} \cdot A C 111_{0}+\sum A C 1^{(1)} \cdot A C 111_{1}+ \\
+\sum A C 1^{(2)} \cdot A C 111_{2}+\sum A C 1^{(a)} \cdot A C 111_{3}+ \\
+\sum A C 1^{(4)} \cdot A C 111_{4}=5.196 . \\
\lambda_{\max }=\lambda_{1} .
\end{gathered}
$$

7. Calculate Consistency Index

$$
C I=\frac{\lambda_{\max }-n}{n-1}=\frac{5,196-5}{5-1}=0,049 .
$$

8. Calculate the consistency ratio. The average random consistency of the matrix of this order $\mathrm{RC}=1,12$

$$
C R=\frac{C I}{R C}=\frac{0,049}{1,12}=0,044 .
$$

The result is the calculation of the local priority vector for a given criterion for its consistency ratio.

The calculation for the following criteria is carried out in the same way.

Global priorities have been calculated for each technology.

Global Priority Vector:

- incineration in drum furnaces $\left(\mathrm{P}_{0}\right)$;

- thermal treatment using pyrolysis (gasification) $\left(\mathrm{P}_{1}\right)$;

- fluidized bed combustion $\left(\mathrm{P}_{2}\right)$;

- burning on mechanical grates $\left(\mathrm{P}_{3}\right)$;

- incineration in metallurgical or cement furnaces $\left(\mathrm{P}_{4}\right)$.

$$
P_{j y}=\left(\begin{array}{l}
P_{0} \\
P_{1} \\
P_{2} \\
P_{9} \\
P_{4}
\end{array}\right)=\left(\begin{array}{l}
3,137 \\
0,758 \\
0,932 \\
1,393 \\
1,821
\end{array}\right) \text {. }
$$


The most important global priority is the $S_{1}$ option combustion in drum furnaces. Further in terms of global priority $\mathrm{S}_{5}-$ combustion in metallurgical and cement furnaces. The smallest indicator in the relatively new technology is treatment using pyrolysis or gasification. Generalized values of local priorities are given in Table 3.

$$
A C 111=\left(\begin{array}{l}
A C 111_{0} \\
A C 111_{1} \\
A C 111_{2} \\
A C 111_{3} \\
A C 111_{4}
\end{array}\right)=\left(\begin{array}{c}
0,515 \\
0,15 \\
0,146 \\
0,092 \\
0,095
\end{array}\right) .
$$

Table 3 - Vectors of local priorities for selection of plants for thermal waste disposal

\begin{tabular}{|c|c|c|c|c|}
\hline ·气 & Local Priority Vector & & 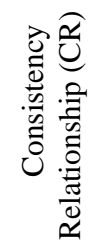 & 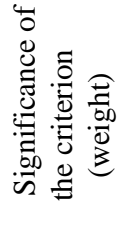 \\
\hline 1 & 2 & & 3 & 4 \\
\hline $\mathrm{C}_{1}$ & $\begin{aligned} A C 111 & =\left(\begin{array}{l}A C 111_{0} \\
A C 111_{1} \\
A C 111_{2} \\
A C 111_{a} \\
A C 111_{4}\end{array}\right) \\
& =\left(\begin{array}{c}0,515 \\
0,15 \\
0,146 \\
0,092 \\
0,095\end{array}\right)\end{aligned}$ & $=$ & 0,044 & 1,0 \\
\hline $\mathrm{C}_{2}$ & $\begin{aligned} A C 222 & =\left(\begin{array}{l}A C 222_{0} \\
A C 222_{1} \\
A C 222_{2} \\
A C 222_{9} \\
A C 222_{4}\end{array}\right) \\
& =\left(\begin{array}{c}0,436 \\
0,07 \\
0,081 \\
0,109 \\
0,305\end{array}\right)\end{aligned}$ & $=$ & 0,046 & 1,0 \\
\hline $\mathrm{C}_{3}$ & $\begin{aligned} A C 333 & =\left(\begin{array}{l}A C 333_{0} \\
A C 333_{1} \\
A C 333_{2} \\
A C 333_{2} \\
A C 333_{4}\end{array}\right) \\
& =\left(\begin{array}{l}0,535 \\
0,078 \\
0,183 \\
0,163 \\
0,041\end{array}\right)\end{aligned}$ & $=$ & 0,046 & 1,0 \\
\hline
\end{tabular}

\begin{tabular}{|c|c|c|c|c|c|}
\hline \multicolumn{6}{|c|}{ Continuation of the table 3} \\
\hline 1 & & 2 & & 3 & 4 \\
\hline $\mathrm{C}_{4}$ & $\begin{aligned} A C 444 & = \\
& =\end{aligned}$ & $\begin{array}{l}\left(\begin{array}{l}A C 444_{0} \\
A C 444_{1} \\
A C 444_{2} \\
A C 444_{2} \\
A C 444_{4}\end{array}\right) \\
\left(\begin{array}{l}0,498 \\
0,067 \\
0,087 \\
0,245 \\
0,104\end{array}\right)\end{array}$ & $=$ & 0,066 & 1,0 \\
\hline $\mathrm{C}_{5}$ & $\begin{array}{r}A C 555= \\
=\end{array}$ & $\begin{array}{l}\left(\begin{array}{l}A C 555_{0} \\
A C 555_{1} \\
A C 555_{2} \\
A C 555_{2} \\
A C 555_{4}\end{array}\right) \\
\left(\begin{array}{l}0,331 \\
0,071 \\
0,093 \\
0,129 \\
0,377\end{array}\right)\end{array}$ & $=$ & 0,052 & 1,0 \\
\hline $\mathrm{C}_{6}$ & $\begin{array}{r}A C 666= \\
=\end{array}$ & $\begin{array}{c}\left(\begin{array}{l}A C 666_{0} \\
A C 666_{1} \\
A C 666_{2} \\
A C 666_{3} \\
A C 666_{4}\end{array}\right) \\
\left(\begin{array}{c}0,435 \\
0,139 \\
0,05 \\
0,05 \\
0,366\end{array}\right)\end{array}$ & $=$ & 0,062 & 1,0 \\
\hline $\mathrm{C}_{7}$ & $\begin{array}{r}A C 777= \\
=\end{array}$ & $\begin{array}{l}\left(\begin{array}{l}A C 777_{0} \\
A C 777_{1} \\
A C 777_{2} \\
A C 777_{3} \\
A C 777_{4}\end{array}\right) \\
\left(\begin{array}{l}0,201 \\
0,106 \\
0,106 \\
0,098 \\
0,488\end{array}\right)\end{array}$ & $=$ & 0,029 & 1,0 \\
\hline $\mathrm{C}_{8}$ & $\begin{array}{r}A C 888= \\
=\end{array}$ & $\begin{array}{l}\left(\begin{array}{l}A C 888_{0} \\
A C 888_{1} \\
A C 888_{2} \\
A C 888_{9} \\
A C 888_{4}\end{array}\right) \\
\left(\begin{array}{l}0,186 \\
0,077 \\
0,186 \\
0,507 \\
0,044\end{array}\right)\end{array}$ & $=$ & 0,044 & 1,0 \\
\hline
\end{tabular}


CONCLUSIONS. The work considers waste disposal technologies: biogas collection at landfills, mechanical and biological treatment of solid waste and thermal processing of mixed waste. Methods of thermal treatment of waste are compared according to the same characteristics. The main requirements for the waste incineration process are formulated, which minimize the environmental impact of this process.

Multi-criteria analysis of options using paired comparisons was carried out, and rational waste management technology was chosen. The technology for waste disposal by incineration in drum/rotary furnaces proved sound. According to the vector of global priorities, the value of the indicator of this technology is almost twice the value of the next 'optimal' technology.

\section{МНОГОКРИТЕРИАЛЬНЫЙ АНАЛИЗ ВЫБОРА ТЕХНОЛОГИИ УТИЛИЗАЦИИ ОТХОДОВ С ИСПОЛЬЗОВАНИЕМ ПАРНЫХ СРАВНЕНИЙ}

\section{Т. В. Гребенюк, Н. С. Ремез, В. В. Прокопенко, В. О. Броницкий}

Национальный технический университет Украины

«Киевский политехнический институт имени Игоря Сикорского»

ул. Борщаговская, 115, Киев, 03056, Украина. E-mail: t.hrebeniuk07@ gmail.com

Существует два основных типа стратегий захоронения отходов. Традиционные свалки, которые не контролируются, допускают выброс загрязняющих веществ в почву без ограничений. Этот метод не считается подходящим для эксплуатации из-за серьезного риска, который может вызвать выщелачивание грунтовых вод и возможное скопление свалочного газа. Следовательно, современные свалки должны контролироваться и эксплуатироваться на основе «технического обслуживания», что позволяет избежать загрязнения окружающей среды. Домашние свалки являются основными источниками загрязнения воздуха выбросами парниковых газов. Проанализированы важные вопросы бытовых свалок, которые являются источниками загрязнения атмосферного воздуха, грунта и подземных вод. Газ, выбрасываемый на свалки, может содержать различные компоненты, которые, как известно, вызывают «парниковый эффект». Выбросы газа и сточных вод со свалок могут происходить в течение десятилетий и сотен лет. Рассмотрены методы утилизации твердых бытовых отходов. Решения по управлению твердыми отходами должны быть финансово устойчивыми, технически осуществимыми, социально, юридически приемлемыми и экологически безопасными. В ходе работы были произведены сравнения существующих методов термической обработки отходов. При сравнении основных технологий утилизации твердых отходов обычно задаются следующие вопросы: какая из них важнее или значительнее; что более вероятно; которое имеет большее преимущество и др. Начиная с оценки целесообразности внедрения конкретной технологии обращения с отходами, решаются две задачи: выбор технологий обращения с отходами и разработка системы критериев, по которым будет проводиться анализ. Для сжигания отходов используется несколько типов оборудования: сжигание во вращающихся печах, термическая обработка с использованием пиролиза, сжигание в псевдосжиженном слое, сжигание на механической решетке, сжигание в металлургических или цементных печах. По результатам исследования эффективность пяти альтернативных методов обращения с отходами оценивалась на основе 8 критериев, проводился метод иерархического анализа. Обоснованная технология утилизации отходов сжиганием в барабанных / вращающихся печах. По вектору глобальных приоритетов ценность этой технологии почти вдвое превышает стоимость следующей «оптимальной» технологии.

Ключевые слова: свалки, загрязнение, технологии утилизация, отходы, термическая обработка, анализ сравнений.

\section{REFERENCES}

1. Stratehiia integrovanoho povodzhennia $z$ tverdymy pobutovymy vidhodamy (TPV) $u$ Tulchynskomu cilovomu rehioni, [Strategy of integrated solid waste management in Tulchyn target region], Tulchyn: DESPRO, 2012. 45 p.

2. Ionel Bistricean D. The impact of municipal solid waste landfills in Suceava County on air quality. GEOREVIEW. 2014. №10. pp. 32-39.

3. A Study on the Economic Valuation of Environmental Externalities from Landfill Disposal and Incineration of Waste. URL: https://ec.europa.eu/environment/waste/studies/pdf/econ y_eva_landfill_annex.pdf

4. Infiltration. Urban Stormwater Management Manual. 2017. №7. pp. 32-36. URL: https://www.water.gov.my/jps/resources/auto\%20downl oad\%20images/58464d5215bbe.pdf
5. Pusch, R., Knutsson, S. (2013), Environmental Impact Assessment for Waste Treatment and Disposal Facilities. Natural Science. № 5. pp. 342-348.

6. Hrebenyuk, T. V., Popach, M. V. (2019), Analiz metodiv termichnoii obrobky tverdyh pobutovyh vidhodiv. [Analysis of methods of heat treatment of solid household waste], Current scientific research in the modern world, № 11. pp. 92-97.

7. Combustion characteristics. URL: http://webserver.dmt.upm.es/ isidoro/bk3/c15/Combust ion\%20characteristics.pdf.

8. Pierucci, S. (2015), Numerical Simulation of Combustion Process of Fuel Gas Mixtures at Refining Industry. Chemical engineeringtransactions. № 43. pp. 1351-1356.

9. Sadaka, S. (2017), Biomass Combustion / S. Sadaka, D. Johnson. Division of agriculture. Research \& Extension. № 3. pp. 156-172. 
10. Cherbina, V. YU., Lobko, S. S. (2016), O povyshenii energoeffektifnosti vrashchaiushchihsia. Mizhnarodna naukova konferenciia Materialy dlia roboti $v$ ekstremalnyh umovah - 6. Kyiv : KPI im. Ihoria Sikorskogo, № 6. pp. 376-380.

11. Balubaid, M., Alamoudi, R. (2015), Application of the analytical hierarchy process (AHP) to multi-criteria analysis for contractor selection. American journal of industrial and business management. № 09. pp. 581-589.

12. Trifonov, A. G. Mnogokriterialnaia optimizaciia [Elektronnyj resurs], available at: http://matlab.exponenta.ru/optimiz/book_1/16.php.

13. Sztekler, K. (2016), Utilization of waste heat from rotary kiln for burning clinker in the cement plant. E3S Web of Conferences. № 10. pp. 3-5.

14. Reuter, M., Yang, Y. (2014), Incineration of hazardous waste in rotary kilns: better understanding through process simulation. Clean Environment for All: Proceedings of the 2nd International Conference on Environmental Concerns. № 10. pp. 1418-1428.
15. Lombardi, F., Lategano, E. (2013), Waste incineration in rotary kilns: A new simulation combustion tool to support design and technical change. Waste Management \& Research. № 4. pp. 740-749.

16. WasteGasification \& Pyrolysis: High Risk,Low Yield Processes for WasteManagement. URL: $\quad$ https://www.no-burn.org/wpcontent/uploads/Waste-Gasification-and-Pyrolysis-highrisk-low-yield-processes-march-2017.pdf.

17. Gasification and Pyrolysis - Reliable Options for Waste Treatment? URL: https://www.vivis.de/wpcontent/uploads/WM3/2012_WM_403_411_Gleis.pdf.

18. Lyalin, V. E., Hajbulin, R. G. (2008), Primeneniie metoda analiza ierarhii dlia otsenki effektivnosti ustanovok termicheskogo unichtozheniia otravliaiushchih veshchestv. Shtuchnyi intelekt. № 4. pp. 103-108.

Стаття надійшла 19.06.2020. 